\title{
The challenges of integrating biodiversity and ecosystem services monitoring and evaluation at a landscape-scale wetland restoration project in the UK
}

\author{
$\underline{\text { Francine M. R. Hughes }}^{1}, \underline{\text { William M. Adams }}^{2}, \underline{\text { Stuart H. M. Butchart }}^{3,4}, \underline{\text { Rob H. Field }}^{5}, \underline{\text { Kelvin S. H. Peh }}^{6,7}$ and Stuart Warrington $^{8}$
}

\begin{abstract}
There is an increasing emphasis on the restoration of ecosystem services as well as of biodiversity, especially where restoration projects are planned at a landscape scale. This increase in the diversity of restoration aims has a number of conceptual and practical implications for the way that restoration projects are monitored and evaluated. Landscape-scale projects require monitoring of not only ecosystem services and biodiversity but also of ecosystem processes since these can underpin both. Using the experiences gained at a landscape-scale wetland restoration project in the UK, we discuss a number of issues that need to be considered, including the choice of metrics for monitoring ecosystem services and the difficulties of assessing the interactions between ecosystem processes, biodiversity, and ecosystem services. Particular challenges that we identify, using two pilot data sets, include the decoupling of monetary metrics used for monitoring ecosystem services from biophysical change on the ground and the wide range of factors external to a project that influence the monitoring results. We highlight the fact that the wide range of metrics necessary to evaluate the ecosystem service, ecosystem process, and biodiversity outcomes of landscape-scale projects presents a number of practical challenges, including the need for high levels of varied expertise, high costs, incommensurate monitoring outputs, and the need for careful management of monitoring results, especially where they may be used in making decisions about the relative importance of project aims.
\end{abstract}

Key Words: biodiversity; ecosystem processes; ecosystem services; landscape-scale; metrics; monitoring; restoration; valuation; Wicken Fen

\section{INTRODUCTION}

The restoration of ecosystem services is now recognized as an important conservation goal, alongside the restoration of biodiversity and ecosystems (Paetzold et al. 2010, Bullock et al. 2011). This reflects a utilitarian turn in conservation, an emphasis on use values as well as intrinsic values in nature (McCauley 2006, Kallis et al. 2013, Mace 2014) and an increasing recognition of the importance of links between the state of nature and human well-being (IPBES 2014, Kenter et al. 2015). The diminishing ability of ecosystems to deliver services (to people) as they become degraded was initially highlighted by the Millennium Ecosystem Assessment in 2003, and aspirations to reverse this trend are now clearly embedded in, for example, the EU's Green Infrastructure Strategy (European Commission 2013) and Aichi Targets 14 and 15 of the Strategic Plan for Biodiversity 2011-2020 agreed by Parties to the Convention on Biological Diversity in October 2010 (CBD 2010). Target 14 is concerned with restoration and safeguarding of essential services; Target 15 relates to the contribution that restoration of $15 \%$ of degraded ecosystems can make to enhancing carbon stocks (CBD date unknown). Through this same period, a greater emphasis on the importance of maintaining social-ecological systems that are resilient and able to deliver ecosystem services in the face of sudden or unexpected change also became mainstream (e.g., Berkes et al. 2003, Rockström et al. 2014) and strengthened the case for integrating ecosystem service restoration into the practice of ecological restoration.

Restoration science and practice have tended to be led by either the aims of biodiversity conservation or of environmental improvement, such as reduced pollution. Frequently, aims of environmental improvement have had an implicit ecosystem services dimension, but it is only recently that this has become more explicit. Where biodiversity aims have been dominant, restoration has often been spatially prescriptive and has tried to restore previously present species, habitats, or landscapes (e.g., Jordan and Packard 1989, Webb 2002). However, there has also been attention to ecosystem processes, especially in dynamic ecosystems, such as many rivers and wetlands. Here, revitalization of ecosystem processes such as water, sediment, and nutrient delivery is advocated, often at the scale of a river reach, or less commonly at a catchment scale with less-prescribed restoration outcomes over space or through time (e.g., Stanford et al. 1996, Palmer et al. 2005, Hughes et al. 2012a). In these cases, there is an emphasis on the continuing dynamic nature of the ecosystem as an embedded restoration goal. Wetland restoration projects with an additional focus on the restoration of ecosystem services need to identify the ecosystem components and processes that support or provide those services and explicitly consider them in the restoration activities.

An appreciation of the critical capacity of wetlands to deliver ecosystem services, and concern over wetland losses prompted some of the earliest work on valuing wetlands (e.g., Gosselink et al. 1974, Odum 1979, Constanza 1984, Folke 1991, Thomas et al. 1991). These and other studies also highlighted the importance of dynamic ecosystem processes in sustaining the capacity of wetlands to deliver multiple ecosystem services over the long term, and thus exposed the mismatch between a functional understanding of wetlands and their services (Sather and Smith 1984, Williams 1990) and the static economic accounting methods used in their monetary valuation (Mitsch and Gosselink 1993 Turner et al. 2008).

In river and wetland restoration, the hydrological catchment has long been used as a natural functional context for large-scale

\footnotetext{
${ }^{1}$ Animal and Environment Research Group, Department of Life Sciences, Anglia Ruskin University, Cambridge, UK, ${ }^{2}$ Department of Geography, University of Cambridge, Cambridge, UK, ${ }^{3}$ BirdLife International, David Attenborough Building, Cambridge, UK, ${ }^{4}$ Department of Zoology, Cambridge, UK, ${ }^{5}$ RSPB Centre for Conservation Science, Royal Society for the Protection of Birds, The Lodge, Sandy, Bedfordshire, UK, ${ }^{6}$ Centre for Biological Sciences, University of Southampton, Southampton, UK, ${ }^{7}$ Conservation Science Group, Department of Zoology, University of Cambridge, Cambridge, UK, ${ }^{8}$ National Trust, Wicken Fen National Nature Reserve, Wicken, Cambridgeshire, UK
} 
restoration of both biodiversity and ecosystem services (Hill et al. 1991, King and Louw 1998, Hughes et al. 2001, Rood et al. 2003). For example, improved water provision is most effectively delivered through restoration of hydrological processes at a catchment scale. This increase in spatial scale for effective ecosystem service restoration is commensurate with the recent emphasis in the UK on landscape-scale conservation for biodiversity (Lawton et al. 2010, JNCC and DEFRA 2012, Adams et al. 2014), which acknowledges the importance of understanding the scales at which ecological processes operate (Poiani et al. 2000), including their abiotic components (Lawler et al. 2015).

The requirement for restoration to take place at a landscape scale and to deliver both ecosystem services and biodiversity has implications for the monitoring and evaluation of such projects. Restoration for biodiversity is conventionally assessed against species or habitat targets (e.g., number or abundance of species, or habitat area and/or condition), often defined in terms of reference systems. However, there are many different ways of choosing biodiversity monitoring metrics depending on aims and resources (Pressey and Bottrill 2009), spatial scale (Redford et al. 2003), and to some degree, disciplinary biases (Nilsson et al. 2014). There is a rapidly growing literature on the relationships between biodiversity and ecosystem services, but this emphasizes the complexity of these relationships (Mace et al. 2012) and methodological difficulties in assessing them (Cardinale et al. 2012). Certainly, there is no simple equivalence between biodiversity and ecosystem service delivery (Adams 2014). Biodiversity targets of restoration projects may be only partially related to ecosystem service targets, except where elements of biodiversity (e.g., rare or charismatic species) underpin cultural ecosystem services such as recreation, or trends in biodiversity mirror those of services as a result of a common underlying process (e.g., increased waterfowl numbers and increased flood-holding capacity in a wetland, both underpinned by increasing waterbody extent). Whole species assemblages play important roles in ecosystem service provision, for example, pollinators, but may not be among those selected as targets or indicators of successful restoration. As a result, metrics for monitoring biodiversity will rarely coincide with those for monitoring ecosystem services. There is also now a considerable literature on one-off assessments of ecosystem services but little on how to monitor ecosystem services through time except by using predictive (often GIS based) modeling or scenario-building approaches that are not linked to monitoring on the ground (e.g., InVEST date unknown).

Monitoring landscape-scale restoration projects can require not only monitoring of ecosystem services and biodiversity but also monitoring of the key ecosystem processes that underpin them (e. g., monitoring of water tables to assess the flood-holding capacity of a wetland in order to assess the potential service of avoided flood damage). Ecosystem process data can help elucidate relationships between ecosystem processes, ecosystem services, and biodiversity, and this understanding may inform management decisions in the future. This complex monitoring situation can lead to practical problems with the choice of suitable monitoring metrics at landscape-scale restoration projects.

We explore the challenges presented by the need to monitor biodiversity, ecosystem processes, and ecosystem services. We identify difficulties, trade-offs, and synergies around these three areas of monitoring, using our experience of monitoring a landscape-scale wetland restoration project in East Anglia, UK: the Wicken Fen Vision project (National Trust 2009). It is not our intention to conduct a critique of the monitoring program as it now exists at the Wicken Fen Vision project, but to consider some of the practical monitoring issues that face managers of projects with such plural aims. We offer our thoughts as a stepping stone toward identifying robust and practical approaches to monitoring such projects. We discuss (1) measuring and monitoring ecosystem services; (2) assessing interactions between ecosystem processes, biodiversity, and ecosystem services; and (3) practical aspects of monitoring a landscape-scale project.

\section{THE WICKEN FEN VISION}

\section{Aims of the Wicken Fen Vision project}

This project was launched in 1999 by the National Trust, a nature conservation nongovernmental organization in the UK. In 1899, the Trust acquired the first parts of a small wetland relic of the once-vast fenlands of East Anglia (Moore 1997). During the 20th century, this acquisition grew into the Wicken Fen National Nature Reserve (called "the reserve" hereafter), an area of 170 ha of alkaline fen and a highly species-rich (> 8000 species) Ramsardesignated wetland of international importance (Friday and Rowell 1997). The reserve is intensively and conventionally managed to conserve the existing high value biodiversity with rotational cutting and removal of vegetation and efforts to maintain water tables well above reclaimed and drained surrounding farmland (Mountford et al. 2005).

The Wicken Fen Vision is a landscape-scale habitat creation project whose aim is to turn (over a 100-year period) 5300 ha of drained and intensively farmed arable land, between the reserve and the city of Cambridge to the southwest, into land dedicated to nature conservation. The project's initial impetus was to help conserve the large number of species (primarily plants and invertebrates, including some rare species with dwindling populations) using the reserve. The Vision acquired its own dynamic because large-scale conservation approaches were becoming important in the UK and because having access to whole hydrological catchments offered a more sustainable approach to creating wetland habitats. In addition, preventing and adapting to climate change had become a political issue, and it was hoped that the change of land use would help reduce the high carbon emissions from intensive arable agriculture on the peat soils of the fens (Colston 2003). Although the Vision area lies adjacent to the reserve, the National Trust recognized that it would not be technically or economically feasible to replicate surviving habitats because of the novel starting point for ecosystem development resulting from more than half a century of intensive drainage and arable agriculture. Because of this, there are no analogues to inform expectations of ecological outcomes at the site (Hughes et al. 2005). The project therefore adopted an open-ended approach to restoration without specified species or habitat targets, but with a main goal of allowing or establishing ecological processes (natural regeneration, naturalistic grazing, and fluctuating, shallow water tables) over a large scale. Subsidiary goals were to create a dynamic wetland landscape characterized by mobile vegetation mosaics, and to increase ecosystem service provision (Hughes et al. 2011).

The Vision landscape was expected to provide a larger area of habitat for some species already found in the reserve, but also for 
additional species. In its Strategy, the National Trust states that it "plans to...greatly expand the space for wildlife and people...to create a dynamic mosaic of...self-regenerating habitats which can be managed less intensively, securing the essential resource of water and protecting peat soils...there is not a prescriptive landscape plan covering the Vision area" (National Trust 2009:3 $\& 9)$. The expectation was that while some habitats would have some species in common with the reserve, in many places, species assemblages would be novel because they would include mixtures of native fen-specific species, native generalists (both wetland and terrestrial species), arable-specific species, and non-native species. There was also an aim to monitor hydrological and ecological processes across restored areas (National Trust 2009).

\section{Outcomes of the Wicken Fen Vision project}

The project area currently covers 770 ha, including the original reserve. On the ground, large areas of former arable land have developed into a habitat mosaic of shallow waterbodies, reed beds, wet grassland, dry grassland, and scrub. The proportions and species composition of these habitats emerging across the new landscape are determined by the nature of the soils and seed banks (Stroh et al. 2012a), the availability of water and soil structure (Stroh et al. 2013), the intensity and nature of different natural processes, including grazing (Stroh 2012), and the need for some forms of occasional management in order to comply with legislation. The natural processes prevailing across the site are both biotic (vegetation regeneration from the seed bank and succession) and abiotic (fluctuating water levels). Semiferal grazing animals (Konik ponies and Highland cattle) have also been introduced into the landscape to act as agents of ecosystem change. The new ecosystem's future trajectory is likely to be influenced by many factors, including the arrival and departure of plants and animals, both antecedent and prevailing environmental conditions, water availability, legislation regarding the control of designated injurious weeds (such as Cirsium vulgare) and animal welfare requirements, and to some degree, local residents. While most local residents and many people from the wider Cambridge area (e.g., walkers, nature-lovers, cyclists, canoeists, horse-riders, educational groups) are very supportive of the project because they enjoy having access to a large nature reserve, there are a few detractors. These are primarily some local farmers who feel that to re-wet drained farmland is countercultural in that area, and a small number of horse-riders who have concerns over the semiferal ponies. All these stakeholders are represented in a user-forum organized by the National Trust that meets several times a year. Other involved stakeholders include the UK Environment Agency, Natural England, researchers, and local parish councillors who are represented on a National Trust advisory committee at Wicken Fen.

In 2011, a one-off assessment of the ecosystem services provided by the Wicken Fen Vision Project was made using the Toolkit for Ecosystem Service Site-based Assessment (TESSA) (Peh et al. 2014). TESSA is a rapid assessment tool that is relatively inexpensive to use and has been applied at a number of protected areas and other sites of biodiversity importance globally (e.g., Birch et al. 2014, Peh et al. 2015, Blaen et al. 2015). This toolkit provides a framework for assessing the value of relevant services at a site currently and under one or more plausible alternative states (Peh et al. 2013). Both current and alternative state services are chosen through discussion with a wide range of stakeholders.
At the Wicken Fen Vision Project, the land converted to wetland was compared against an alternative state of intensively farmed arable land (which is the land use that would still prevail if wetland restoration had not taken place), and the net value of the land use conversion was calculated (Peh et al. 2014). The services that were identified as having been gained or increased in value as a result of the land use conversion at the Wicken Fen Vision project and that were considered to be measurable included nature-based recreation, grazing, flood protection, and reduced greenhouse gas (GHG) emissions (Peh et al. 2014). Other services identified but not considered to be currently measurable included pollination services, improved water quality, improved soil quality, and several cultural services. The main service lost was arable production.

Overall results, based on the measurable services, suggested that in 2011, restoration was associated with a net gain to society as a whole of US\$199 ha-1 $\mathrm{y}^{-1}$, for a one-off investment in restoration of US\$2320 ha $\mathrm{ha}^{-1}$. This included an estimated loss of arable production of US\$2040 ha $\mathrm{y}^{-1} \mathrm{y}^{-1}$ but estimated gains of US\$671 $\mathrm{ha}^{-1} \mathrm{y}^{-1}$ in nature-based recreation, US\$120 ha $\mathrm{ha}^{-1} \mathrm{y}^{-1}$ from grazing (commercial animals were used for a few years on part of the site), US\$48 ha ${ }^{-1} \mathrm{y}^{-1}$ from flood protection, and a reduction in GHG emissions worth an estimated US\$72 $\mathrm{ha}^{-1} \mathrm{y}^{-1}$. Management costs of the wetland compared with arable land were also estimated to have declined by US\$1325 ha- $\mathrm{y}^{-1}$ (Peh et al. 2014).

\section{Monitoring the Wicken Fen Vision project}

Much conservation monitoring in protected sites in England is carried out under and toward tightly prescribed management plans and defined species and habitat targets; e.g., Common Standards Monitoring (CSM) (JNCC 2014). Landscape-scale restoration projects, on the other hand, can adopt a more processdriven approach to restoration, accepting that landscapes and the species within them are in a state of constant flux and that outcomes may be somewhat "open-ended" (Hughes et al. 2012b). This recognition necessitates a different approach to monitoring that is not directed toward measuring progress against set habitat or species targets but is more of a surveillance exercise to track change. A considerable ad hoc species-recording effort has taken place at the original reserve over many decades, with more recent use of the CSM system against agreed habitat targets. However, monitoring during the early stages of the Wicken Fen Vision project was very restricted. In 2007, a new monitoring program was designed for the new restoration area. Monitoring activities were designed against five primary emerging landscape characteristics and the ecosystem processes driving those changes (Table 1): (1) larger areas of land available for plants and animals to colonize and use; (2) higher levels of habitat connectivity through the landscape; (3) greater heterogeneity of habitats that change over space and through time; (4) new, active ecosystem processes contributing to habitat heterogeneity; and (5) different types and levels of ecosystem service delivery. Many monitoring activities use traditional biodiversity and habitat monitoring approaches (in which professionals and volunteers already have skills), as well as newer technologies, to understand the progression of the project against its aims. Many are on 5-year or longer monitoring cycles, reflecting the slow speed of expected change and the long-term nature of the project (Fig. 1). Others are on annual or more frequent cycles, reflecting the need to understand some types of data at this frequency but also the need 
Table 1. Landscape-scale restoration project monitoring protocols at the Wicken Fen Vision Project (developed from Hughes et al. 2011).

\begin{tabular}{|c|c|c|}
\hline $\begin{array}{l}\text { Characteristic of } \\
\text { landscape-scale } \\
\text { restoration project }\end{array}$ & $\begin{array}{l}\text { Expected changes relative to } \\
\text { starting point }\end{array}$ & $\begin{array}{l}\text { Activities to monitor these changes and } \\
\text { monitoring frequencies }\end{array}$ \\
\hline $\begin{array}{l}\text { Larger areas of land } \\
\text { available for use by } \\
\text { plants and animals } \\
\text { (This includes larger } \\
\text { areas of the broad } \\
\text { habitat types, } \\
\text { including open water, } \\
\text { reed beds, wet and } \\
\text { dry grassland, scrub, } \\
\text { and woodland.) }\end{array}$ & $\begin{array}{l}\text { Arrival of visiting or breeding } \\
\text { "landscape species"" not } \\
\text { previously present; e.g., raptors, } \\
\text { common cranes, roe deer, red deer, } \\
\text { or migratory birds }\end{array}$ & $\begin{array}{l}\text { Annual or 5-yearly counts of } \\
\text { "landscape species"; e.g., wetland bird } \\
\text { counts are carried out monthly } \\
\text { following a British Trust for } \\
\text { Ornithology protocol (WeBS)" }\end{array}$ \\
\hline
\end{tabular}

Higher numbers of some species which now appear in large numbers, having previously been Fen in great numbers; e.g., owls, birds in small numbers

Ad hoc, annual, or 5-yearly counts of species that have appeared at Wicken of prey, waterfowl, deer, butterflies

\section{WeBS counts}

Higher levels of habitat connectivity through the landscape to facilitate species movement

(This includes more opportunities for rare or specialist species to find a functional niche beyond current protected areas.)

\section{Greater}

heterogeneity of habitats reflecting a wider range of biophysical conditions and ecological processes within a larger area; these habitat mosaic will change over space and through time.

More active (both expected and unexpected) ecosystem processes contributing to habitat heterogeneity

More seasonally varied water tables and seasonal flooding

Arrival of species that have negotiated a new connection or gap in the landscape; e.g., butterfly species not previously present, as well as landscape species

Arrival of "hotspot species" - rare or specialist species that have previously been confined to Wicken Fen National Nature Reserve (NNR), especially invertebrates and plants

Development of novel and changing wetland and drier vegetation assemblages associated with novel edaphic conditions (e.g., novel soil structure and chemistry from past land use); some may resemble vegetation communities in the UK National Vegetation Classification, but most will not Natural vegetation regeneration
Vegetation surveys to capture regeneration and succession
Extensive invertebrate survey method designed specifically for Wicken Fen Vision (Kirby 2010, 2011, 2012, 2013); the approach involves repeat transects through wetland habitats, a wide range of wetland invertebrate groups identified to species level, and assignment of conservation significance scores; annual or 5-yearly surveys

Landscape species counts

Annual or less frequent surveys that might locate animal or plant hotspot species previously confined to Wicken Fen NNR; examples include annual quadrat surveys for plants, annual Wwalk surveys for plants, and invertebrate surveys

Vegetation surveys using fixed quadrats to capture regeneration and succession Comparison of vegetation in 2007 and 2012 using False Colour Infra-Red aerial photo-mosaics to describe change in vegetation mosaics, e.g., heterogeneity and vegetation wetness indices, turnover metrics
The aim is to track the arrival and departure of species that can only either visit or become resident if the area is large enough for them. Their presence marks a scale change in available habitats. It is recognized that bird numbers are highly dependent on conditions elsewhere, not just on conditions in the project area; e.g., the visits by common cranes (Grus grus) are new since the start of the project and reflect more available habitat at the Wicken Fen Vision, but also at other nearby large-scale wetland creation projects.

The aim is to catalogue wildlife spectacles not previously present rather than species not previously present. These data are mostly in the form of ad hoc counts or reports made by staff and interested visitors, but for some bird species are also picked up by monthly wetland bird counts.

GIS mapping of new connections was not considered useful since it shows only the potential for a species to occupy or use a connection, not whether it has actually used the connection. Furthermore, it is not known for most invertebrate species what types of connections they need (Öckinger and Smith 2008), and it is likely that species responses to landscape change reflect complex interdependencies (Didham et al. 2012) which cannot be mapped.

Results show slow movement of plant species from the NNR onto restoration land (Stroh et al. 2012a) but do include some regionally rare aquatic plant species (e.g., Zannichellia palustris) not previously recorded at Wicken Fen; Kirby (2012) shows arrival of a few invertebrate species; e.g., Cerapheles terminatus and Agabus undulatus.

Analysis of vegetation using TABLEFIT ${ }^{\S}$ in 2007 showed low fit with UK National Vegetation Classification vegetation categories, as expected. This may be repeated in 2017, the next monitoring year in the 5-yearly monitoring cycle. However, results from 2007 and 2012 suggest that it may not be useful to use this approach more frequently than every 10 years.
Stroh et al. (2013) quantify the relationships between soil structure, hydrology, and vegetation using Sum Exceedance Values, and show how this approach can be used to monitor these relationships at Wicken Fen Vision.
Continuous or monthly measurement of hydrological variables, including water table depth (using data loggers in dipwells), rainfall, soil moisture 
Self-reliant, reproducing grazing herd
Annual counts and observation of grazing/browsing animal numbers

Arrival and departure of other grazing or browsing animals, such as deer

Different types and levels of ecosystem service delivery
Decrease in carbon and increase in methane emissions

Improved water quality
Automated continuous measurement of carbon and methane fluxes

Annual monitoring of "environmental indicator species"; e.g., aquatic macrophytes, monitored using protocol for aquatic macrophytes (Buglife Version 2 2007), as well as simpler approaches listing species presence

Increased flood protection through Monitoring of water tables in water storage (avoided flood damage)

Increased opportunities for recreational, educational, and aesthetic activities

Increased provision of grazing land designated flood storage area using automated dipwells

Monitoring of recreational and educational use; visitor numbers are monitored by the National Trust, as is use of the reserve by educational groups Monitoring of grazing animals; this is carried out by the National Trust
Additional data were collected on the potential of grazing animals to act as dispersers of plant propagules (Stroh et al. $2 b$ ). It would be desirable to monitor browsing impact of ungulates, but this has not yet been undertaken.
Research has been underway since late 2009 by University of Leicester, Open University, and UK Natural Environment Research Council - Centre for Ecology and Hydrology.

It would be desirable to also measure water quality on a regular basis; however, aquatic macrophytes are a good indication of overall quality conditions (e.g., Palmer 2001).

A one-off assessment of avoided flood damage was made in 2011 (Peh et al. 2014).

The methods used for a one-off calculation of recreational service in 2011 are given in Peh et al. (2014).

A one-off assessment of grazing value was made in 2011 (Peh et al. 2014).

${ }^{\dagger}$ The term "landscape species" has been borrowed from the Wildlife Conservation Society, which defines them as species that use large diverse areas and/ or that can have significant impact on the structure and function of ecosystems (WCS 2001).

" http://www.bto.org/volunteer-surveys/webs/data

$\S$ http://www.ceh.ac.uk/services/tablefit-and-tablcorn

to retain experienced volunteers who will tend to fall away unless monitoring activities are undertaken regularly.

\section{MEASURING AND MONITORING ECOSYSTEM SERVICES}

Monitoring ecosystem services at a restoration project requires decisions on which services to monitor and which metrics to use for measuring them. Choice of services can be based on emerging habitats, changes in soil cover, and interactions between the natural world and people since the same habitat in two different places may offer different services depending on both the use made of the habitat and the perception of that use (Zorilla-Miras et al. 2014). Choice of services can thus be a complex dimension of monitoring. At the Wicken Fen Vision project, once services offered by the project had been identified and some of them had been measured in a one-off assessment (Peh et al. 2014), we identified two particularly pertinent remaining challenges: (1) accounting for services that are difficult to measure either in biophysical or monetary units, and (2) extending beyond a oneoff assessment to monitor ecosystem services through time.

\section{Accounting for services that are difficult to measure}

Water quality leaving the project area is undoubtedly better than when the site was under arable land use, since there are no longer applications of fertilizers, herbicides, or pesticides. However, there is also less water leaving the site, which has impacts on pollution dilution effects within the catchment. Lack of pointsource outlets for measuring these effects was the reason that this service was difficult to measure and therefore not included in the assessment by Peh et al. (2014). Aquatic macrophytes can give an indication of water quality through changing species composition, diversity, and abundance, and have been monitored in the project area but cannot easily be translated into ecosystem service values. For example, the arrival of regionally rare species such Zannichellia palustris and of abundant Potamogeton coloratus on the Wicken Fen Vision site are indicators of improving water quality, although there are other confounding factors that may account for their presence, including connectivity of waterbodies and the species' relative dispersal ability.

Enhanced wildlife populations in the project area are monitored through a range of biodiversity monitoring activities listed in Table 1 . The value of the more charismatic birds, mammals, and plants as a "good" to people is in part accounted for through measurement of recreational services. Less-charismatic species (e.g., saprophytic invertebrates) that may provide services indirectly through their influence on ecosystem processes, such as soil formation, are not. Nonrecreational cultural services, such as existence values, are also not valued, but there is a large literature debating whether or not such valuations should be carried out (e.g., Adams 2014, Silvertown 2015). These are unavoidable problems with any attempt at comprehensive valuation of ecosystem services and may be addressed by adopting more pluralistic valuation frameworks (Gómez-Baggethun et al. 2014, Martin-López et al. 2014).

\section{Monitoring ecosystem services through time}

Any variable will change over time as the result of long-term trends, of periodic, sometimes regular fluctuations, and of random variation in influential factors. Projection of past trends into the future relies either on an assumption that factors operating in the 
Fig. 1. Conceptual diagram of monitoring activities at the Wicken Fen Vision project (GHG: greenhouse gas).

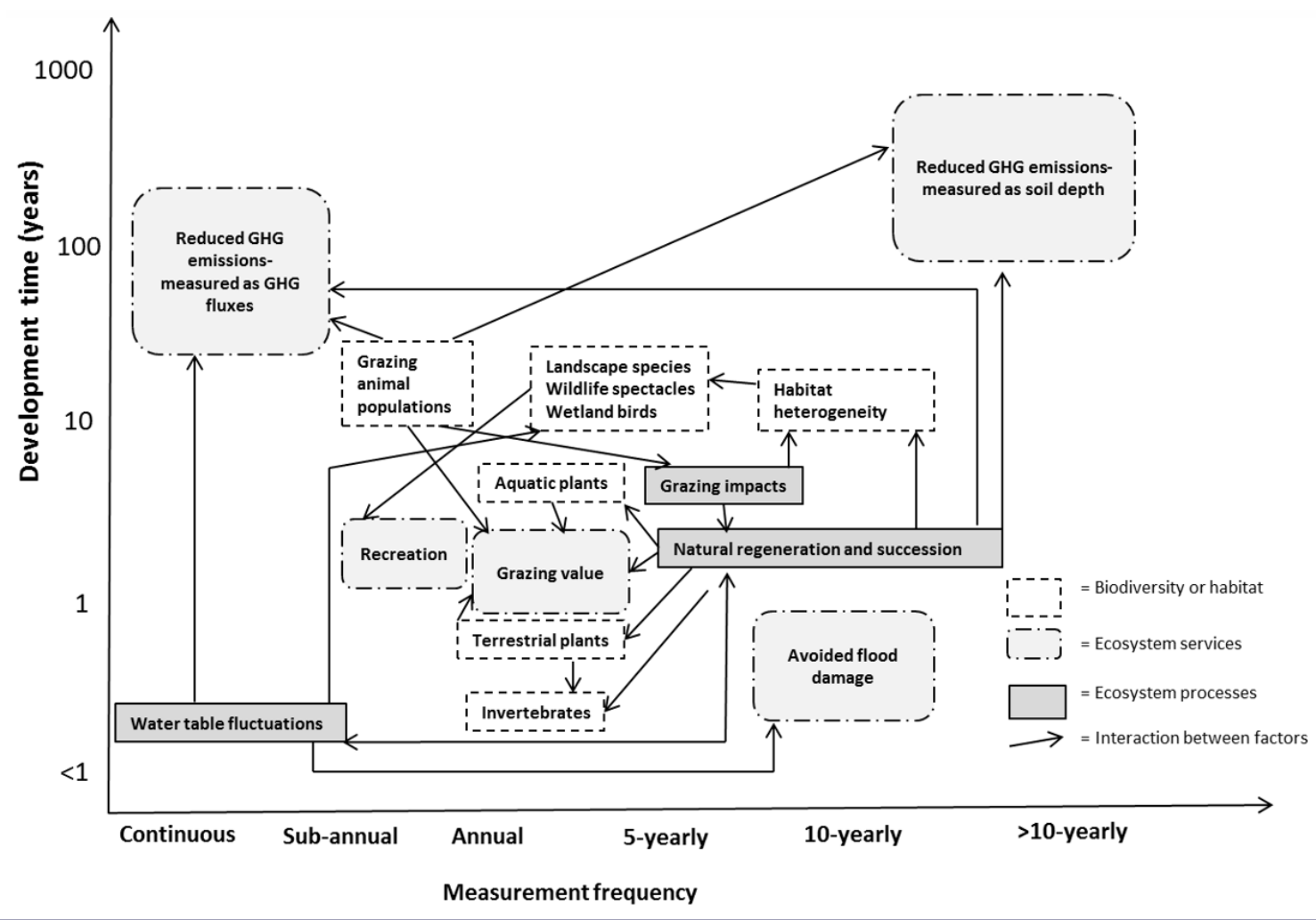

past will continue into the future or on plausible scenario building. Future projections of ecosystem service delivery require understanding of the relationships between the state of natural capital and the likely sustainability of ecosystem service provision over the long term. For this, monitoring data are required for both the natural capital and the ecosystem services. When monitoring ecosystem services, existing data on a service can inform the likely magnitude of spatial and temporal variation, and hence the sampling design and intensity that is required. In particular, such data can be used to find an appropriate balance between cost and sensitivity of the measurement method against likelihood of detecting statistically significant change that is also of practical interest to project managers. However, the relative size of inter- and intra-annual change compared with likely longer term change may be difficult to gauge in the early stages of monitoring, meaning that sampling design may need to be modified over time.

Different ecosystem services change over very different time frames, adding to the monitoring challenge (Fig. 1). For example, recreational services can change substantially between years, but carbon sequestration in re-wetted peat soils is very slow, measurable over decadal time frames. Loss of drained peat soils (and stored carbon) occurs rapidly, currently at rates of 7-21 $\mathrm{mm} \mathrm{yr}^{-1}$ depth in the fens of East Anglia (Holman 2009), and reduction in rate of soil loss is also measurable over shorter time frames, contributing to our understanding of reduced GHG emissions. Ecosystem service monetary values can change through time as a result of real biophysical change on the ground, shifts in market prices (often a reflection of wider socio-economic factors such as demand and scarcity), and changes in inflation rates. The first of these is of greatest interest to a landscape-scale restoration project, but monetary values are often easier to obtain than biophysical measurements and can provide a common currency for comparison across services or capital.

The 2011 ecosystem services assessment of the Wicken Fen Vision project (Peh et al. 2014) demonstrated a measure of the societal value of the project in that year but did not give information about the ecosystem's ability to continue to provide those services into the future. We used the data from the 2011 study to support a desk-based monitoring assessment over a 4-year period, 2011 to 2014 (Table 2), in a preliminary exploration of issues that might arise.

In 2011, the number of paying visitors to the reserve was used along with visitor survey data to derive the value of the cultural ecosystem service represented by recreational visits (Peh et al. 2014). The proportions of visitors who visited the reserve or the restoration area or both in 2011 (Peh et al. 2014) were used in conjunction with visitor numbers for 2012-2014 to update the values to 2014. Recreational value increased over the 4 years. The value of avoided flood damage did not vary because there is a fixed flood storage area that can hold water if the nearby River Cam floods, and this volume would prevent flooding in a fixed area occupied by arable land and other properties whose value was calculated in 2011 (Peh et al. (2014). A more complex version of this calculation could account for the changing risk of flooding each year with time since the previous flood and with antecedent 
Table 2. Ecosystem service values of the Wicken Fen Vision project for 2011-2014.

\begin{tabular}{|c|c|c|c|c|c|}
\hline Ecosystem service metric & 2011 & 2012 & 2013 & 2014 & Calculation method \\
\hline Number of paying visitors $^{\dagger}$ & 44,813 & 46,402 & 50,117 & 55,836 & $\begin{array}{l}\text { Visitors to the original reserve have to pay; visitor } \\
\text { year runs March-February }\end{array}$ \\
\hline $\begin{array}{l}\text { Nature-based recreational value } \\
(\mathrm{US} \$)^{*}\end{array}$ & 350,051 & 362,463 & 391,483 & 436,156 & $\begin{array}{l}\text { Calculation based on paying visitor numbers to the } \\
\text { reserve; assumes } 2011 \text { proportions of visitors to the } \\
\text { reserve and to Wicken Fen Vision land (Peh et al. } \\
2014 \text { ) }\end{array}$ \\
\hline Avoided flood damage (US\$) & 25,119 & 25,119 & 25,119 & 25,119 & Does not take into account changing flood risk \\
\hline $\begin{array}{l}\text { Avoided greenhouse gas emissions } \\
\left.\text { (tonnes } \mathrm{CO}_{2} \text { eq. } \mathrm{y}^{-1}\right)^{\ddagger}\end{array}$ & 1,514 & 1,541 & 1,661 & 1,647 & $\begin{array}{l}\text { Varies with amount of } \mathrm{N}_{2} \mathrm{O} \text { and } \mathrm{CH}_{4} \text { emitted by } \\
\text { changing numbers of horses and cattle each year } \\
\text { (includes feral and commercial animals) }\end{array}$ \\
\hline $\begin{array}{l}\text { Avoided greenhouse gas emissions } \\
\text { (U.S. Govt.) (US\$) })^{\ddagger}\end{array}$ & 168,862 & 177,603 & 199,666 & 206,148 & $\begin{array}{l}\text { U.S. Government Interagency Working Group on } \\
\text { Social Cost of Carbon (SCC), July 2015; } 95^{\text {th }} \\
\text { percentile of SCC estimates at } 3 \% \text { discount rate in } \\
2007 \text { US } \$ \text { values: } \$ 90(2011), \$ 93(2012), \$ 97(2013) \text {, } \\
\$ 101 \text { (2014) tonne } \mathrm{CO}_{2} \text {; incorporates updated cattle } \\
\text { and horse numbers }\end{array}$ \\
\hline $\begin{array}{l}\text { Avoided greenhouse gas emissions } \\
\text { (Verified Emission Reductions) } \\
(\text { US\$) })^{\ddagger \S}\end{array}$ & 10,219 & 9,590 & 8,331 & 6,259 & $\begin{array}{l}\text { Verified Emission Reductions for arable and wetland } \\
\text { (Peters-Stanley and Gonzalez 2014, Hamrick 2015): } \\
\$ 6.20(2011), \$ 5.9(2012), \$ 4.9(2013), \$ 3.8(2014) \\
\text { tonne }^{-1} \mathrm{CO}_{2} \text {; incorporates updated cattle and horse } \\
\text { numbers }\end{array}$ \\
\hline Commercial grazing (US\$) ${ }^{*}$ & 62,394 & 15,402 & 3,170 & 3,079 & $\begin{array}{l}\text { Values reflect fewer commercial grazing animals and } \\
\text { changing licence fees in } 2012,2013 \text {, and } 2014\end{array}$ \\
\hline
\end{tabular}

\footnotetext{
${ }^{\dagger}$ Values for visitor numbers from the National Trust

\$ Original 2011 net service values are for the 479 ha of the Wicken Fen Vision project assessed by Peh et al. (2014). All values have been updated for each year using the methods described in the final column. All monetary values have been adjusted for inflation to 2014, using bank of England inflation rates.

${ }^{\S}$ In Peh et al. (2014), the SCC value used was $\$ 22.78$ tonne ${ }^{-1} \mathrm{CO}_{2}$ based on Greenspan Bell and Callan (2011). Recent remodeling of the SCC values (U. S. Government 2015) puts these costs at higher levels, as used in this table. The Verified Emission Reductions reflect trading prices for carbon. Emissions from arable land calculated for 2011 (Peh et al. 2014) have been assumed unchanged in 2012-2014 calculations.
}

soil conditions and associated soil storage capacity at the time of flooding, but this would be challenging to implement owing to data requirements. After 2012, commercial grazing was reduced on the area used in the 2011 evaluation, so the monetary value of grazing declined in 2013 and 2014. However, the ecological impact of grazing did not decline as animals with a commercial value were replaced with semiferal grazing animals that currently have no commercial value.

The 2011 estimate of climate regulation through avoided GHG emissions took into account both carbon dioxide and methane emissions. Monitoring the value of this service over time presents four practical problems: (1) the year-to-year changes on the ground are difficult and expensive to measure in biophysical units, (2) the service value when arable land is converted to wetland can be calculated only in terms of the net change to GHG emissions (since both land uses emit GHG), which requires monitoring of emissions in both land use types, (3) market economics drive carbon prices, so monetary values are divorced from biophysical change on the ground, and (4) land use sustainability is not reflected in monitoring values.

In 2011, the estimates of avoided losses of GHGs were calculated in tonnes of $\mathrm{CO}_{2}$ eq. $\mathrm{y}^{-1}$ using site data on area and type of each habitat, numbers of grazing horses and cattle, and published emissions factors (Peh et al. 2014). This approach is a reasonable best estimate for a one-off assessment, but its limitation is revealed when cross-year comparisons are made. In biophysical terms, GHG emissions vary within and between years based on many factors, including vegetation development, water table fluctuations, and air temperatures, but only within-year as opposed to cross-year variations tend to be accounted for in published emission factors. The only elements of the GHG calculations in Table 2 that reflect real changes on the ground relate to changing numbers of cows and horses between years because although local emissions factors are available for the main habitats, they do not report on annual variation (more than one year's data are used to derive a single mean annual flux). Vegetation, water table fluctuations, and air temperatures are all monitored at the Wicken Fen Vision project, but it is not easy to use these data to inform the GHG calculations unless monitoring of GHG fluxes also takes place so that statistical relationships between the two can be developed. GHG flux monitoring began at the Wicken Fen Vision project in late 2009 (carbon dioxide) (Morrison et al. 2012) and in 2013 (methane). First results for carbon emissions at the restoration site show that in 2010 it was a near-neutral annual source of carbon $\left(+26.4 \pm 13.7 \mathrm{~g} \mathrm{C} \mathrm{m}^{-2} \mathrm{yr}^{-1}\right)$ but a sink during the growing season and a source outside it (Morrison et al. 2012). When more years of data are available, it will be possible to make across-year comparisons that reflect real change on the ground. However, for most restoration projects, this facility is too technical and expensive to install and maintain. It may be possible over much longer time periods to refine the use of published emissions factors for monitoring $\mathrm{GHG}$ emissions by combining them with vegetation monitoring based on stratified sampling designs in order to capture the changes from, for example, grassland to scrub or changes in management or 
Table 3. Selected annual monitoring data from the Wicken Fen Vision project. Bivariate correlation analyses between pairs of variables, using Pearson correlation tests, show only one weakly significant correlation between visitor numbers and waterfowl numbers $(r 6=$ $0.709, R 2=0.503, p=0.049$ ). Numbers of all species of wetland birds are counted monthly by volunteers on part of the Wicken Fen Vision Project, using the British Trust for Ornithology Wetland Bird Surveys (WeBS) protocol. ${ }^{\dagger}$ The WeBS year runs from July to June. Depth of water table below ground level values are collected from data loggers at the main site where the WeBS counts are made. Visitor numbers are those that pay to visit the National Nature Reserve (NNR) area of Wicken Fen. The whole of the Wicken Fen Vision area is free to visit. Visitor surveys by Peh et al. (2014) showed that $28 \%$ of all visitors visited only the NNR, $42 \%$ visited only the restoration project area, and 30\% visited both the NNR and the project area (the visitor year runs from March to February).

\begin{tabular}{|c|c|c|c|c|c|c|c|c|}
\hline & 2007 & 2008 & 2009 & 2010 & 2011 & 2012 & 2013 & 2014 \\
\hline \multicolumn{9}{|l|}{ Ecosystem service } \\
\hline Number of paying visitors ${ }^{\star}$ & 39,497 & 40,631 & 39,572 & 41,081 & 44,813 & 46,402 & 50,117 & 55,836 \\
\hline \multicolumn{9}{|l|}{ Ecosystem process } \\
\hline $\begin{array}{l}\text { Mean water table depth-summer low water } \\
\text { levels (May-Oct) }\end{array}$ & 0.50 & 0.59 & 1.01 & 0.65 & 1.11 & 0.32 & 0.94 & 0.40 \\
\hline \multicolumn{9}{|l|}{ levels (Nov-April) ${ }^{\S}$} \\
\hline \multicolumn{9}{|l|}{ Biodiversityl } \\
\hline Number of waterfowl & 2459 & 1204 & 2176 & 1190 & 2134 & 1397 & 2134 & 4843 \\
\hline Number of wading birds & 407 & 1067 & 1036 & 244 & 395 & 398 & 344 & 841 \\
\hline \multicolumn{9}{|c|}{${ }^{\dagger}$ http://www.bto.org/volunteer-surveys/webs/data } \\
\hline \multicolumn{9}{|c|}{ Visitor data provided by the National Trust and used as a surrogate for recreational service } \\
\hline \\
\hline \multicolumn{9}{|c|}{$\begin{array}{l}\text { 'All wetland bird data from the British Trust for Ornithology WeBS online data for Wicken Fen } \\
\text { 'Allon }\end{array}$} \\
\hline
\end{tabular}

husbandry methods. The use of proxies and remote sensing for estimating site emissions and/or carbon stocks is becoming more feasible but still requires substantial time and financial input (e.g., Couwenberg et al. 2011, Willcock et al. 2012), although this would still cost less than obtaining direct measurements. Currently, these remain coarse tools compared with the actual response of GHG emissions to small-scale changes in biophysical factors (Morrison et al. 2013). None of these methods gives information about future sustainability of the arable and restoration land uses, though this is clearly higher for restoration land given its much lower rate of soil loss.

The biggest interannual changes in GHG emission values in Table 2 result not from biophysical change but from market economics. There are numerous different possible carbon prices that can be used to turn the biophysical estimate into a monetary value, and Table 2 shows the results of monitoring using two of these. The first includes the Social Cost of Carbon (U.S. Government 2015) and shows high values increasing from 2011 to 2014, while the second reflects real carbon market prices (Peters-Stanley and Gonzalez 2014, Hamrick 2015) and shows low values going down over the same period; both are decoupled from the actual biophysical changes taking place on the ground except for the changing numbers of cattle and horses.

\section{ASSESSING INTERACTIONS BETWEEN ECOSYSTEM PROCESSES, BIODIVERSITY, AND ECOSYSTEM SERVICES}

We have already suggested that some ecosystem services, such as nature-based recreation, are more obviously underpinned by biodiversity than others. However, where the biodiversity varies in response to the physical state of the ecosystem, the three-cornered relationship between biodiversity, ecosystem process, and ecosystem services becomes more difficult to interpret. For example, at the Wicken Fen Vision project, visitors are attracted by wildlife spectacles such as large flocks of wetland birds on the extensive waterbodies that form during the winter months. Links might therefore be expected between water table levels, wetland bird numbers, and recreational services (measured in visitor numbers). Annual data over an 8-year period show only one weakly significant relationship between these variables (Table 3). We acknowledge that if the data were reported at finer timescales, they might show different relationships during different periods. However, the lack of strong correlations between these variables is not surprising because many other factors are implicated in each part of this relationship, both on- and off-site, and all factors are changing over different time frames. The spectacle of large numbers of wetland birds draws visitors, but visitor numbers are also influenced by weather, the state of the economy, a growing local human population, and publicity events at the restoration project. Wetland bird numbers are influenced by many factors well beyond the project area, including the proximity, availability, and habitat quality of waterbodies at a number of other largescale wetland creation sites within the southern part of the Fenland region (four such projects lie within $30 \mathrm{~km}$ of the project), and the conditions along migratory routes and at summer breeding grounds elsewhere on the globe. The water table conditions are influenced by rainfall and by water abstraction under licence from the UK Environment Agency.

These relationships are further complicated by other factors, including issues of marginality, lag effects, and sustainability. Marginality issues affect some services more than others. For example, in relation to climate regulation, GHG emissions are directly proportional to land area (albeit with likely fine-scale variability), whereas recreational services are not, so monitoring data need to be interpreted with this in mind. Lag effects between changing ecosystem processes and components are highly variable, and it is difficult to assess how they influence ecosystem services over time since it is not possible to measure all the 
variables (Tallis et al. 2008). Hence, even if measuring the resulting service is possible, it may not be possible to understand why its value changes and therefore how sustainably the services can be provided into the future (Palmer and Febria 2012).

\section{PRACTICAL ASPECTS OF MONITORING A LANDSCAPE-SCALE PROJECT}

\section{Monitoring logistics, cost, and required expertise}

Monitoring a landscape-scale restoration project necessarily requires monitoring over a large spatial extent because of the large functional boundaries of relevant ecosystem processes. It also requires monitoring over long time frames because biodiversity, ecosystem processes, and ecosystem services vary interdependently through very different time frames in response to many exogenous and endogenous factors. It further requires many more factors to be monitored, some of which are conceptually complex, expensive in practice, and difficult to interpret, and may be beyond the practical capacity of a restoration project. There are only a few synergies to be found between monitoring areas in terms of their required metrics. For example, at the Wicken Fen Vision project, data on numbers of grazing animals form part of biodiversity monitoring, inform the calculations of changing GHG fluxes, and contribute to interpretation of changing vegetation communities over time. Where and how to deposit monitoring data can also be problematic and increases in scope as the numbers of metrics and people involved increase. Issues that need resolving include data quality control, access, intellectual property, and governance.

Data collection across so many different monitoring areas requires a wide range of qualified professional and volunteer personnel and a budget to cover professional time and equipment where required. At the Wicken Fen Vision project, one-off capital equipment costs of monitoring included automated dipwells, False-Colour InfraRed (FCIR) aerial photography, and installation of grazing exclosures. Personnel costs in the first 5 years of the monitoring program (2007-2012) included a full-time monitoring officer plus consultant specialists for invertebrate surveys and analysis of the FCIR imagery. More than 50 volunteers engaged with monitoring during this period, but maintaining volunteer engagement between years can be difficult, and it was concluded that paid monitoring personnel are essential for consistent and regular monitoring of critical areas.

\section{The importance of monitoring to engage stakeholders}

Monitoring can also play an important role in landscape-scale projects in alleviating the concerns of local stakeholders. At the Wicken Fen Vision project, there were initial, unfounded, local concerns about potential flooding of homes, and it was useful to be able to demonstrate knowledge of water tables across the project area by providing water table monitoring data. Peh et al. (2014) subsequently demonstrated that the project delivers a net benefit in terms of avoided flood damage. Monitoring the ecosystem services that the new landscape offers can have a useful public relations role to play in such projects since many stakeholders may be more interested in economic benefits than biodiversity outcomes. A regular project newsletter is delivered by the National Trust to all households in villages and settlements adjacent to the project (approximately 22,000 households), and includes reports on aspects of science and monitoring.
Involvement and training of local volunteers in the monitoring program helps engage people with the project and improves perceptions of it.

\section{Interpreting and using monitoring results}

Monitoring both biodiversity and ecosystem services can provide data to aid decision-making, but it is important that data provision does not subvert management objectives. For example, investment in nongreen infrastructure such as additional access routes to maximize visitor numbers may, if not planned carefully, reduce the abundance of species of conservation interest which are the primary objective. At the Wicken Fen Vision project, yearround static shallow water tables would probably provide optimal reductions in GHG reductions (Morrison et al. 2012), but in most wetlands, varied inter- and intra-annual water table fluctuations are necessary to promote natural regeneration of many vegetation communities and to provide diverse habitat conditions through the year for a variety of animal species (Hughes et al. 2012a, Ausden et al. 2014). Stabilizing water tables may also reduce the maintenance of habitats that have beneficial effects on long-term reduction of emissions. Thus, monitoring can inform decisionmaking at a landscape-scale restoration site, but it is important to be clear about the relative importance of objectives related to biodiversity restoration and ecosystem service provision (Casazza et al. 2016).

\section{CONCLUSION}

Mindful of all these challenges, we provide practical recommendations to begin to address them at a project level. Addressing these challenges is important because Payments for Ecosystem Services and offsetting schemes are increasingly based on restoration projects and should relate to actual delivery of services and biodiversity on the ground as well as to their ability to sustain both of these into the future. For example, some extant schemes currently accept the use of proxy methods of assessing GHG emissions reductions (e.g., Tanneberger and Wichtmann 2011).

\section{Consider what each monitoring variable tells you before choosing to monitor it}

Time frames over which significant changes can be detected will determine the frequency and intensity of monitoring required for different metrics. Choosing metrics can be difficult; for example, choice of ecosystem process metrics to monitor requires a good understanding of which biotic and abiotic factors are coupled. Some metrics can contribute to monitoring several different aspects, as demonstrated by grazing data at Wicken Fen. In general, however, different metrics are required for different kinds of monitoring. Understanding relationships between the sensitivity of measuring methods, sampling design, and likely magnitude of spatial and temporal change is important in all types of monitoring. Where possible, confidence intervals should be reported, and uncertainties in data validity highlighted, even if only in qualitative terms.

Choosing which ecosystem services to measure is best approached through a consensual approach and in conjunction with a wide range of project stakeholders. This approach is recommended in the TESSA toolkit (Peh et al 2013). Biophysical metrics are better than monetary metrics for understanding change on the ground, but monetary metrics can provide common units for comparison 
of ecosystem services. Overall, we advocate a pluralistic approach to valuation of ecosystem services, with careful consideration of when monetary values can be used and when alternatives should be sought. Approaches to value pluralism are currently being refined, for example, in the discussion of integrated valuation by Gómez-Baggethun et al. (2014).

Consider how and to whom you report your monitoring results Reporting the achievements of a project in terms of biodiversity metrics gives a very different context for valuing its achievements compared with reporting its achievements in terms of ecosystem service provision because the value of the biodiversity may not be tightly correlated with the value of the service. Different stakeholders are likely to have different views on the respective values of these two dimensions (Ruckelshaus et al. 2015). Choice of monitoring metrics and the incompatibilities of measurement scale and sampling design of many biodiversity and ecosystem service metrics can have a significant impact on the results reported, on who values a restoration project, on perceptions of cost-effectiveness, and on how decisions are made based on the monitoring results.

\section{Consider the long term}

Over time, landscape-scale wetland restoration projects can expect biodiversity and ecosystem services delivery to change in response to both endogenous and exogenous factors. Any project, however well-defined its targets, is on a trajectory of ecosystem change. These changes need to be factored into project expectations and to any Payment for Ecosystem Services or offsetting schemes associated with them. It is important that projects do not attempt to create static ecosystems to ensure stable delivery of ecosystem services, since this would not only have detrimental effects on many wetland species and habitats but also be unsustainable in the long term.

Responses to this article can be read online at: http://www.ecologyandsociety.org/issues/responses. $\mathrm{php} / 8616$

\section{Acknowledgments:}

This research is linked to grants EN 06-2151 and 09-2739 from the Esmée Fairbairn Foundation to FH and to research by members of the Toolkit for Ecosystem Service Site-based Assessment (TESSA) steering committee. At Wicken Fen (National Trust), we thank John Bragg for data on water tables, Carol Laidlaw for data on grazing animals, and Isabel Sedgwick for visitor data. Martin Lester and the late Ralph Sargent (National Trust) carried out the WeBS counts at Wicken Fen. Dr. Dawn Hawkins (Anglia Ruskin University) provided expertise on statistics, and Professor Andrew Balmford (University of Cambridge), useful comments.

\section{LITERATURE CITED}

Adams, W. M. 2014. The value of valuing nature. Science 346:5495517. http://dx.doi.org/10.1126/science.1255997

Adams, W. M., I. D. Hodge, and L. Sandbrook. 2014. New spaces for nature: the re-territorialisation of biodiversity conservation under neoliberalism in the UK. Transactions of the Institute of British Geographers 39:574-588. http://dx.doi.org/10.1111/ $\underline{\operatorname{tran} .12050}$

Ausden, M., G. Hirons, L. Lock, and G. White. 2014. Managing and re-creating wetlands in Britain for potential colonists. British Birds 107:726-755.

Berkes, F., J. Colding, and C. Folke, editors. 2003. Navigating social-ecological systems: building resilience for complexity and change. Cambridge University Press, Cambridge, UK. http://dx. doi.org/10.1017/cbo9780511541957

Birch, J. C., I. Thapa, A. Balmford, R. B. Bradbury, C. Brown, S. H. M. Butchart, H. Gurung, F. M. R. Hughes, M. Mulligan, B. Pandeya, K. S-H. Peh, A. J. Stattersfield, D. H. L. Thomas, and M. Walpole. 2014. What benefits do community forests provide, and to whom? A rapid assessment of ecosystem services from a Himalayan forest, Nepal. Ecosystem Services 8:118-127. http:// dx.doi.org/10.1016/j.ecoser.2014.03.005

Blaen, P. J., L. Jia, K. S.-H. Peh, R. H. Field, A. Balmford, M. A. MacDonald, and R. B. Bradbury. 2015. Rapid assessment of ecosystem services provided by two mineral extraction sites restored for nature conservation in an agricultural landscape in Eastern England. PLoS ONE 10(4):e0121010. http://dx.doi. org/10.1371/journal.pone. 0121010

Bullock, J. M., J. Aronson, A. C. Newton, R. Pywell, and J. M. Rey-Benayas. 2011. Restoration of ecosystem services and biodiversity: conflicts and opportunities. Trends in Ecology \& Evolution 26:541-549. http://dx.doi.org/10.1016/j.tree.2011.06.011

Cardinale, B. J., J. E. Duffy, A. Gonzalez, D. U. Hooper, C. Perrings, P. Venail, A. Narwani, G. M. Mace, D. Tilman, D. A. Wardle, A. P. Kinzig, G. C. Daily, M. Loreau, J. B. Grace, A. Larigauderie, D. S. Srivastava, and S. Naeem. 2012. Biodiversity loss and its impact on humanity. Nature 486:59-67. http://dx.doi. org/10.1038/nature11148

Casazza, M. L., C. T. Overton, T.-V. D. Bui, J. M. Hull, J. D. Albertson, V. K. Bloom, S. Bobzien, J. McBroom, M. Latta, P. Olofson, T. M. Rohmer, S. Schwarzbach, D. R. Strong, E. Grijalva, J. K. Wood, S. M. Skalos, and J. Takekawa. 2016. Endangered species management and ecosystem restoration: finding the common ground. Ecology and Society 21(1):19. http:// dx.doi.org/10.5751/ES-08134-210119

Colston, A. 2003. Beyond preservation: the challenge of ecological restoration. Pages 247-267 in W. M. Adams, and M. Mulligan, editors. Decolonizing nature: strategies for conservation in a post-colonial era. Earthscan, London, UK.

Convention on Biological Diversity (CBD). 2010. COP 11 Decision X/2. Strategic plan for biodiversity 2011-2020. [online] URL: http://www.cbd.int/decision/cop/?id=12268

Convention on Biological Diversity (CBD). Date unknown. Aichi biodiversity targets. [online] URL: https://www.cbd.int/sp/ targets/

Costanza, R. 1984. Natural resource valuation and management: toward ecological economics. Pages 7-18 in A. M. Jansson, editor. Integration of economy and ecology-an outlook for the eighties. University of Stockholm Press, Stockholm, Sweden. 
Couwenberg, J., A. Thiele, F. Tanneberger, J. Augustin, S. Bärisch, D. Dubovik, N. Liashchynskaya, D. Michaelis, M. Minke, A. Skuratovich, and H. Joosten. 2011. Assessing greenhouse gas emissions from peatlands using vegetation as a proxy. Hydrobiologia 674:67-89. http://dx.doi.org/10.1007/s10750-011-0729$\underline{\mathrm{x}}$

Didham, R. K., V. Kapos, and R. M. Ewers. 2012. Rethinking the conceptual foundations of habitat fragmentation research. Oikos 121:161-170. http://dx.doi.org/10.1111/j.1600-0706.2011.20273. $\underline{\mathrm{x}}$

European Commission. 2013. Building a green infrastructure for Europe. Publications Office of the European Union, Luxembourg.

Folke, C. 1991. The societal value of wetland life-support. Pages 141-171 in C. Folke and T. Kaberger, editors. Linking the natural environment and the economy. Kluwar Academic Publishers, Dordrecht, The Netherlands. http://dx.doi.org/10.1007/978-94-$\underline{017-6406-3 \quad 8}$

Friday, L. E., and T. A. Rowell. 1997. Patterns and processes. Pages 11-21 in L. Friday, editor. Wicken Fen: the making of a wetland nature reserve. Harley Books, Colchester, UK.

Gómez-Baggethun, E. B., B. Martín-López, D. Barton, L. Braat, H. Saarikoski, E. Kelemen, M. García-Lorente, J. van den Bergh, P. Arias, P. Berry, M. Potschin, H. Keene, R. Dunford, C. SchröterSchlaack, and P. Harrison. 2014. State-of-the-art report on integrated valuation of ecosystem services. EU FP7 OpenNESS Project Deliverable 4.1., European Commission FP7.

Gosselink, J. G., E. P. Odum, and R. M. Pope. 1974. The value of the tidal marsh. Louisiana State University, Center for Wetland Resources, Baton Rouge, Louisiana, USA.

Greenspan Bell, R., and D. Callan. 2011. More than meets the eye: the social cost of carbon in U.S. climate policy, in plain English. Policy brief. World Resources Institute, Washington, D.C., USA.

Hamrick, K. 2015. Ahead of the curve: the state of the voluntary carbon markets 2015. Forest Trends' Ecosystem Marketplace, Washington, D.C., USA.

Hill, M., W. S. Platts, and R. L. Beschta. 1991. Ecological and geomorphological concepts for instream and out-of-channel flow requirements. Rivers 2:319-343.

Holman, I. P. 2009. An estimate of peat reserves and losses in the East Anglian fens commissioned by the RSPB. Department of Natural Resources, Cranfield University, UK.

Hughes, F. M. R., W. M. Adams, E. Muller, C. Nilsson, K. S. Richards, N. Barsoum, H. Decamps, R. Foussadier, J. Girel, H. Guilloy, A. Hayes, M. Johansson, L. Lambs, G. Pautou, J.-L. Peiry, M. Perrow, F. Vautier, and M. Winfield. 2001. The importance of different scale processes for the restoration of floodplain woodlands. Regulated Rivers: Research \& Management 17:325-345. http://dx.doi.org/10.1002/rrr.656

Hughes, F. M. R., W. M. Adams, and P. A. Stroh. 2012b. When is open-endedness desirable in restoration projects? Restoration Ecology 20:291-295. http://dx.doi.org/10.1111/j.1526-100X.2012.00874. $\underline{\mathrm{x}}$
Hughes, F. M. R., A. Colston, and J. O. Mountford. 2005. Restoring riparian ecosystems: the challenge of accommodating variability and designing restoration trajectories. Ecology and Society 10(1):12. [online] URL: http://www.ecologyandsociety. org/vol10/iss1/art12/

Hughes, F. M. R., M. G. del Tanago, and J. O. Mountford. $2012 a$. Restoring floodplain forests in Europe. Pages 393-422 in J. Stanturf, P. Madsen, and D. Lamb, editors. A goal-oriented approach to forest landscape restoration. Springer-Verlag, Dordrecht, The Netherlands. http://dx.doi.org/10.1007/978-94-007-5338-9 15

Hughes, F. M. R., P. A. Stroh, W. M. Adams, K. Kirby, J. O. Mountford, and S. Warrington. 2011. Monitoring and evaluating large-scale, 'open-ended' habitat creation projects: a journey rather than a destination. Journal for Nature Conservation 19:245253. http://dx.doi.org/10.1016/j.jnc.2011.02.003

Intergovernmental Science-Policy Platform on Biodiversity and Ecosystem Services (IPBES). 2014. Preliminary guide regarding diverse conceptualization of multiple values of nature and its benefits, including biodiversity and ecosystem functions and services. IPBES/3/INF/7.

InVEST: integrated valuation of ecosystem services and tradeoffs (InVEST). Date unknown. [online] URL: http://www. naturalcapitalproject.org/invest/

Joint Nature Conservation Committee (JNCC). 2014. Common Standards Monitoring (CSM). [online] URL: http://jncc.defra. gov.uk/page-2217

Joint Nature Conservation Committee and Department for Environment, Food \& Rural Affairs (JNCC and Defra). 2012. The UK Post-2010 Biodiversity Framework. [online] URL: http:// jncc.defra.gov.uk/page-6189

Jordan, W. R., and S. Packard. 1989. Just a few oddball species: restoration practice and ecological theory. Pages 18-26 in G. P. Buckley, editors. Biological habitat reconstruction. Belhaven Press, London, UK.

Kallis, G., E. Gómez-Baggethun, and C. Zografos. 2013. To value or not to value? That is not the question. Ecological Economics 94:97-105. http://dx.doi.org/10.1016/j.ecolecon.2013.07.002

Kenter, J. O., L. O'Brien, N. Hockley, N. Ravenscroft, I. Fazey, K. N. Irvine, M. S. Reed, M. Christie, E. Brady, R. Bryce, A. Church, N. Cooper, A. Davies, A. Evely, M. Everard, R. Fish, J. A. Fisher, N. Jobstvogt, C. Molloy, J. Orchard-Webb, S. Ranger, M. Ryan, V. Watson, and S. Williams. 2015. What are shared and social values of ecosystems? Ecological Economics 111:86-99. http://dx.doi.org/10.1016/j.ecolecon.2015.01.006

King J., and D. Louw. 1998. Instream flow requirements for regulated rivers in South Africa using the Building Block Methodology. Aquatic Ecosystem Health and Management 1:109124. http://dx.doi.org/10.1016/S1463-4988(98)00018-9

Kirby, P. 2010. Wicken Fen Vision and Great Fen invertebrate surveys 2009. Report to Anglia Ruskin University, Cambridge UK.

Kirby, P. 2011. Wicken Fen Vision and Great Fen invertebrate surveys 2010. Report to Anglia Ruskin University, Cambridge UK. 
Kirby, P. 2012. Wicken Fen Vision and Great Fen invertebrate surveys 2011. Report to Anglia Ruskin University, Cambridge UK.

Kirby, P. 2013. Wicken Fen Vision and Great Fen invertebrate surveys 2012. Report to Anglia Ruskin University, Cambridge UK.

Lawler, J. J., D. D. Ackerley, C. M. Albano, M. G. Anderson, S. Z. Dobrowski, J. L. Gill, N. E. Heller, R. L. Pressey, E. W. Sanderson, and S. B. Weiss. 2015. The theory behind, and the challenges of, conserving nature's stage in a time of rapid change. Conservation Biology 29:618-629. http://dx.doi.org/10.1111/ $\underline{\text { cobi. } 12505}$

Lawton, J. H., P. N. M. Brotherton, V. K. Brown, C. Elphick, A. H. Fitter, J. Forshaw, R. W. Haddow, S. Hilborne, R. N. Leafe, G. M. Mace, M. P. Southgate, W. A. Sutherland, T. E. Tew, J. Varley, and G. R. Wynne. 2010. Making space for nature: a review of England's wildlife sites and ecological network. Report to Defra, UK Government.

Mace, G. M. 2014. Whose conservation? Science 345:1558-1560. http://dx.doi.org/10.1126/science.1254704

Mace, G. M., K. Norris, and A. H. Fitter. 2012. Biodiversity and ecosystem services: a multi-layered relationship. Trends in Ecology \& Evolution 27:19-26. http://dx.doi.org/10.1016/j.tree.2011.08.006

Martín-López, B., E. Gómez-Baggethun, M. García-Llorente, and C. Montes. 2014. Trade-offs across value domains in ecosystem service assessment. Ecological Indicators 37:220-228. http://dx.doi.org/10.1016/j.ecolind.2013.03.003

McCauley, D. J. 2006. Selling out on nature. Nature 43:27-28.

Mitsch, W. J., and J. G. Gosselink. 1993. Wetlands. First edition. Van Nostrand Reinhold, New York, USA.

Moore, N. W. 1997. The Fenland Reserves. Pages 3-8 in L. Friday, editor. Wicken Fen: the making of a wetland nature reserve. Harley Books, Colchester, UK.

Morrison, R., A. M. J. Cumming, H. E. Taft, J. Kaduk, S. E. Page, D. L. Jones, R. J. Harding, and H. Baltzer. 2013. Carbon dioxide fluxes at an intensively cultivated temperate lowland peatland in the East Anglian fens, UK. Biogeosciences Discussions 10:41934223. http://dx.doi.org/10.5194/bgd-10-4193-2013

Morrison, R., J. Kelvin, P. A. Stroh, S. E. Page, F. M. R. Hughes, J. Kaduk, M. Acreman, R. Harding, and H. Baltzer. 2012. Net ecosystem carbon dioxide exchange at semi-natural and regenerating temperate fens. Extended abstract, $14^{\text {th }}$ International Peat Congress, Bangor, UK.

Mountford, J. O., A. Colston, and M. Lester. 2005. Management for diversity: the sedge and litter vegetation at Wicken Fen NNR in 2004. Nature in Cambridgeshire 47:15-23.

National Trust. 2009. Wicken Fen Vision: a National Trust strategy to create a 53 square kilometre nature reserve for wildlife and people in Cambridgeshire. National Trust, Wicken, Cambridgeshire, UK.

Nilsson, C., L. E. Polvi, J. Gardeström, E. M. Hasselquist, L. Lind, and J. M. Sarneel. 2014. Riparian and in-stream restoration of boreal streams and rivers: success or failure? Ecohydrology 8:753-764. http://dx.doi.org/10.1002/eco.1480
Őckinger, E., and H. G.Smith. 2008. Do corridors promote dispersal in grassland butterflies and other insects? Landscape Ecology 23:27-40. http://dx.doi.org/10.1007/s10980-007-9167-6

Odum, E. P. 1979. The value of wetlands: a hierarchical approach. Pages 16-25 in P. E. Greeson, J. R. Clark, and J. E. Clark, editors. Wetland functions and values: the state of our understanding. American Water Resources Association Technical Publication, Minneapolis, Minnesota, USA.

Paetzold, A., P. H. Warren, and L. L. Maltby. 2010. A framework for assessing ecological quality based on ecosystem services. Ecological Complexity 7:273-281. http://dx.doi.org/10.1016/j. ecocom.2009.11.003

Palmer, M. A. 2001. An approach to the use of macrophytes for monitoring standing waters. Freshwater Forum 16:82-90.

Palmer, M. A., E. S. Bernhardt, J. D. Allan, P. S. Lake, G. Alexander, S. Brooks, J. Carr, S. Clayton, C. N. Dahm, J. Follstad Shah, D. L. Galat, S. G. Loss, P. Goodwin, D. D. Hart, B. Hassett, R. Jenkinson, G. M. Kondolf, R. Lave, J. L. Meyer, T. K. O'Donnell, L. Pagano, and E. Sudduth. 2005. Standards for ecologically successful river restoration. Journal of Applied Ecology 42:208-217. [online] URL: http://onlinelibrary.wiley. com/doi/10.1111/j.1365-2664.2005.01004.x/full http://dx.doi.org/10.1111/ j.1365-2664.2005.01004.X

Palmer, M., M. Drake, and N. Stewart. 2007. A manual for the survey and evaluation of the aquatic plant and invertebrate assemblages of ditches. Version 2, Buglife, Peterborough, UK.

Palmer, M. A., and C. M. Febria. 2012. The heartbeat of ecosystems. Science 336:1393-1394. http://dx.doi.org/10.1126/ science. 1223250

Peh, K. S-H., A. Balmford, J. C. Birch, C. Brown, S. H. M. Butchart, J. Daley, J. Dawson, G. Gray, F. M. R. Hughes, S. Mendes, J. Millett, A. J. Stattersfield, D. H. L. Thomas, M. Walpole, and R. B. Bradbury. 2015. Potential impact of invasive alien species on ecosystem services provided by a tropical forested ecosystem: a case study from Montserrat. Biological Invasions 17:461-475. http://dx.doi.org/10.1007/s10530-014-0743-9

Peh, K. S.-H., A. Balmford, R. B. Bradbury, C. Brown, S. H. M. Butchart, F. M. R. Hughes, A. Stattersfield, D. H. L. Thomas, M. Walpole, J. Bayliss, D. Gowing, J. P. G. Jones, S. L. Lewis, M. Mulligan, B. Pandeya, C. Stratford, J. R. Thompson, K. Turner, B. Vira, S. Willcock, and J. Birch. 2013. TESSA: a toolkit for rapid assessment of ecosystem services at sites of biodiversity conservation importance. Ecosystem Services 5:51-57. [online] URL: http://dx.doi.org/10.1016/j.ecoser.2013.06.003

Peh, K. S-H., A. Balmford, R. H. Field, A. Lamb, J. C. Birch, R. B. Bradbury, C. Brown, S. H. M. Butchart, M. Lester, R. Morrison, I. Sedgwick, C. Soans, A. J. Stattersfield, P. A. Stroh, R. D. Swetnam, D. H. L. Thomas, M. Walpole, S. Warrington, and F. M. R. Hughes. 2014. Benefits and costs of ecological restoration: rapid assessment of changing ecosystem service values at a U.K. wetland. Ecology and Evolution 4:3875-3886. http://dx.doi.org/10.1002/ece3.1248

Peters-Stanley, M., and G. Gonzalez. 2014. Sharing the stage: state of the voluntary carbon markets, 2014. Forest Trends' Ecosystem Marketplace, Washington, D.C., USA. 
Poiani, K. A., B. D. Richter, M. G. Anderson, and T. M. Richter. 2000. Biodiversity conservation at multiple scales: functional sites, landscapes, and networks. Bioscience 50:133-146. http://dx. doi.org/10.1641/0006-3568(2000)050[0133:BCAMSF]2.3.CO;2

Pressey, R. L., and M. C. Botrill. 2009. Approaches to landscapeand seascape-scale conservation planning: convergence, contrasts and challenges. Oryx 43:464-475.

Redford, K. H., P. Coppolillo, E. W. Sanderson, G. A. B. Da Fonseca, E. Dinerstein, C. Groves, G. Mace, S. Maginnis, R. A. Mittermeier, R. Noss, D. Olson, J. G. Robinson, A. Vedder, and M. Wright. 2003. Mapping the conservation landscape. Conservation Biology 17:116-131. http://dx.doi.org/10.1046/ j.1523-1739.2003.01467.x

Rockström, J., M. Falkenmark, C. Folke, M. Lannerstad, J. Barron, E. Enfors, L. Gordon, J. Heinke, H. Hoff, and C. PahlWostl, editors. 2014. Water resilience for human prosperity. Cambridge University Press, Cambridge, UK. http://dx.doi. org/10.1017/cbo9781139162463

Rood, S. B., C. R. Gourley, E. M. Ammon, L. G. Heki, J. R. Klotz, M. L. Morrison, D. Mosley, G. G. Scoppettone, S. Swanson, and P. L. Wagner. 2003. Flows for floodplain forests: successful riparian restoration. Bioscience 53:647-656. http://dx.doi. org/10.1641/0006-3568(2003)053[0647:FFFFAS]2.0.CO;2

Ruckelshaus, M., E. McKenzie, H. Tallis, A. Guerry, G. Daily, P. Kareiva, S. Polasky, T. Ricketts, N. Bhagabati, S. A. Wood, and J. Bernhardt. 2015. Notes from the field: lessons learned from using ecosystem service approaches to inform real-world decisions. Ecological Economics 115:11-21. http://dx.doi. org/10.1016/j.ecolecon.2013.07.009

Sather, J. M., and R. D. Smith. 1984. An overview of major wetland functions and values. U.S. Fish and Wildlife Service FWS/ OBS-84/18, Washington, D.C., USA.

Silvertown, J. 2015. Have ecosystem services been oversold? Trends in Ecology \& Evolution 30:641-648. http://dx.doi. org/10.1016/j.tree.2015.08.007

Stanford, J. A., J. V. Ward, W. J. Liss, C. A. Frissell, R. N. Williams, J. A. Lichatowich, and C. C. Coutant. 1996. A general protocol for restoration of regulated rivers. Regulated Rivers: Research \& Management 12:391-413. http://dx.doi.org/10.1002/(SICI)1099-1646 (199607)12:4/5<391::AID-RRR436>3.0.CO;2-

Stroh, P. A. 2012. Wetland restoration on ex-arable land: the influence of seed banks, propagule dispersal, grazing and soil hydrology. Dissertation. Anglia Ruskin University, Cambridge, UK.

Stroh, P. A., F. M. R. Hughes, T. H. Sparks, and J. O. Mountford. $2012 a$. The influence of time on the soil seed bank and vegetation across a landscape-scale wetland restoration project. Restoration Ecology 20:103-112. http://dx.doi.org/10.1111/j.1526-100X.2010.00740. $\underline{x}$

Stroh, P. A., J. O. Mountford, Y. N. Araya, and, F. M. R. Hughes. 2013. Quantifying soil hydrology to explain the development of vegetation at an ex-arable wetland restoration site. Wetlands 33:311-320. http://dx.doi.org/10.1007/s13157-013-0385-1
Stroh, P. A., J. O. Mountford, and F. M. R. Hughes. 2012b. The potential for endozoochorous dispersal of temperate fen plant species by free-roaming horses. Applied Vegetation Science 15:359-368. http://dx.doi.org/10.1111/j.1654-109X.2011.01172. $\underline{x}$

Tallis, H., P. Kareiva, M. Marvier, and A. Chang. 2008. An ecosystem services framework to support both practical conservation and economic development. Proceedings of the National Academy of Sciences of the United States of America 105:9457-9464. http://dx.doi.org/10.1073/pnas.0705797105

Tanneberger, F., and W. Wichtmann. 2011. Carbon credits from peatland rewetting: climate, biodiversity, land use. Schweizerbart Science Publishers, Stuttgart, Germany.

Thomas, D. H. L., F. Ayache, and G. E. Hollis. 1991. Use and non-use values in the conservation of Ichkeul National Park, Tunisia. Environmental Conservation 18:119-130.

Turner, R. K., S. Georgiou, and B. Fischer. 2008. Valuing ecosystem services: the case of multi-functional wetlands. Earthscan, London, UK.

United States Government Interagency Working Group on Social Cost of Carbon. 2015. Technical support document: technical update of the social cost of carbon for regulatory impact analysisunder executive order 12866.

Webb, N. R. 2002. Atlantic heathlands. Pages 401-418 in M. R. Perrow and A. J. Davey, editors. Handbook of ecological restoration. Volume 2. Restoration in practice. Cambridge University Press, Cambridge, UK.

Wildlife Conservation Society (WCS). 2001. The landscape species approach - a tool for site-based conservation. Living Landscape Program, Bulletin 2.

Williams, M. 1990. Understanding wetlands. Pages 1-42 in M. Williams, editor. Wetlands: a threatened landscape. Blackwell, Oxford, UK.

Willcock, S., O. L. Phillips, P. J. Platts, A. Balmford, N. D. Burgess, J. C. Lovett, A. Ahrends, J. Bayliss, N. Doggart, K. Doody, E. Fanning, J. Green, J. Hall, and S. L. Lewis. 2012. Towards regional, error-bounded landscape carbon storage estimates for datadeficient areas of the world. PloS ONE 7:e44795. http://dx.doi. org/10.1371/journal.pone.0044795

Zorrilla-Miras, P., I. Palomo, E. Gómez-Baggethun, B. MartinLópez, P. L. Lomas, and C. Montes. 2014. Effects of land-use change on wetland ecosystem services: a case study in the Doñana marshes (SW Spain). Landscape and Urban Planning 122:160174. http://dx.doi.org/10.1016/j.landurbplan.2013.09.013 